\section{Change of $\mathrm{HbA}_{1 \mathrm{c}}$ reporting to the new SI units}

TO THE EDITOR: The position statement by Jones and colleagues regarding the change of $\mathrm{HbA}_{1 \mathrm{c}}$ reporting to the new Système International (SI) units - which has been recommended by the Australasian Association of Clinical Biochemists, the Australian Diabetes Educators Association, the Australian Diabetes Society and the Royal College of Pathologists of Australasia — provides a comprehensive summary of the rationale behind the proposed change and suggests a 2-year period of dual reporting. 1

However, Jones et al did not specify targets for children and adolescents, and we believe that it is important to do so. The incidence of type 1 diabetes in Australian children and adolescents is among the highest in the world ${ }^{2}$ and, in New South Wales, type 2 diabetes represents at least $10 \%$ of cases of newonset diabetes in adolescents. ${ }^{3}$ National evidence-based clinical care guidelines for type 1 diabetes in children, adolescents and adults ${ }^{4}$ include agespecific targets for $\mathrm{HbA}_{1 c^{\prime}}$, while recognising that such targets are predominantly consensus based.

$\mathrm{HbA}_{1 \mathrm{c}}$ targets for young people with type 1 diabetes are higher, with a level of $<7.5 \%$ recommended for children and adolescents in the Australian guidelines ${ }^{4}$ and in those produced by the International Society for Pediatric and Adolescent Diabetes (ISPAD). ${ }^{5}$ Jones et al note that "Achievement of $\mathrm{HbA}_{1 \mathrm{c}}$ targets must be balanced against risk of severe hypoglycaemia, especially among older people ${ }^{\prime \prime} ;{ }^{1}$ this is also the case for young people. For children and adolescents with type 2 diabetes, the ISPAD guidelines recommend an $\mathrm{HbA}_{1 \mathrm{c}}$ target of $<7 \%{ }^{5}$

The move to SI units represents a major change in the established, widely recognised outcome measure of glycaemia; during the transition period, the specific needs of young people with diabetes must not be forgotten.

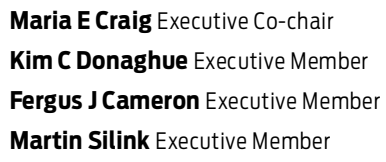

Australian Type 1 Diabetes Guidelines Expert Advisory Group (Australasian Paediatric Endocrine Group and Australian Diabetes Society), Institute of Endocrinology and Diabetes, The Children's Hospital at Westmead, Sydney, NSW.

m.craig@unsw.edu.au

Competing interests: No relevant disclosures. doi: 10.5694/mjall.11018

1 Jones GRD, Barker G, Goodall I, et al. Change of $\mathrm{HbA}_{\mathrm{lc}}$ reporting to the new SI units [position statement]. Med J Aust 2011; 195: 45-46.

2 Catanzariti L, Faulks K, Moon L, et al. Australia's national trends in the incidence of type 1 diabetes in 0-14-year-olds, 2000-2006. Diabet Med 2009; 26: 596-601.

3 Craig ME, Femia G, Broyda V, et al. Type 2 diabetes in Indigenous and non-Indigenous children and adolescents in New South Wales. Med J Aust 2007; 186: 497-499.

4 Craig ME, Twigg SM, Donaghue KC, et al; Australian Type 1 Diabetes Guidelines Expert Advisory Group. National evidence-based clinical care guidelines for type 1 diabetes in children, adolescents and adults. Canberra: Australian Government Department of Health and Ageing, 2011.

5 Rewers M, Pihoker C, Donaghue K, et al. Assessment and monitoring of glycemic control in children and adolescents with diabetes. Pediatr Diabetes 2009; 10 Suppl 12: 71-81. 
IN REPLY: We appreciate Craig and colleagues' comments regarding the importance of reporting general $\mathrm{HbA}_{1 \mathrm{c}}$ targets for children and adolescents with type 1 and type 2 diabetes. In our position statement, the headings of Box 2 and Box 3 indicated that the targets listed were for adults with type 1 diabetes and adults with type 2 diabetes, respectively. ${ }^{1}$ While it is not possible to highlight every clinical situation, we agree that providing general $\mathrm{HbA}_{1 \mathrm{c}}$ targets for children and adolescents will add value to our article, and we have updated it accordingly, ${ }^{1}$ recognising the differences in these targets for type 1 diabetes ( $\leqslant 58 \mathrm{mmol} / \mathrm{mol}, \leqslant 7.5 \%$ ) and type 2 diabetes ( $\leqslant 53 \mathrm{mmol} / \mathrm{mol}$, $\leqslant 7.0 \%) \cdot{ }^{2-4}$ In the interests of uniformity and simplicity, the paediatric targets expressed as " $<$ "2-4 have been adjusted to " $\leqslant$ ", which represents differences of less than $1.5 \%$ of the target values.

Graham R D Jones Chemical Pathologist ${ }^{1}$

George Barker Diabetes Educator ${ }^{2}$

Ian Goodall Scientist in Charge, Complex Chemistry ${ }^{3}$

Hans-Gerhard Schneider Director of Pathology ${ }^{4}$

Mark D S Shephard Director of Community Point of Care Services $^{5}$

Stephen M Twigg Head of Endocrinology ${ }^{6}$

1 St Vincent's Hospital, Sydney, NSW.

2 Hornsby Ku-ring-gai Health Service, Sydney, NSW.

3 Austin Health, Melbourne, VIC.

4 Alfred Health, Melbourne, VIC.

5 Flinders University Rural Clinical School, Adelaide, SA. 6 Royal Prince Alfred Hospital, Sydney, NSW.

gjones@stvincents.com.au

Competing interests: No disclosures other than those listed previously.

doi: 10.5694/mjal1.11131

1 Jones GRD, Barker G, Goodall I, et al. Change of $\mathrm{HbA}_{1 \mathrm{c}}$ reporting to the new SI units [position statement]. Med J Aust 2011; 195: 45-46.

2 Craig ME, Twigg SM, Donaghue KC, et al; Australian Type 1 Diabetes Guidelines Expert Advisory Group. Draft national evidence-based clinical care guidelines for type 1 diabetes in children, adolescents and adults. Canberra: Australian Government Department of Health and Ageing, 2011.

3 Rewers M, Pihoker C, Donaghue K, et al. Assessment and monitoring of glycemic control in children and adolescents with diabetes. Pediatr Diabetes 2009; 10 Suppl 12: 71-81.

4 Rosenbloom AL, Silverstein JH, Amemiya S, et al. Type 2 diabetes in the child and adolescent.

Pediatr Diabetes 2009; 10 Suppl 12: 17-32. 